Лопатченко I.M., к.держ.упр., ННВЦ НУЦЗУ, м. Харків, ORCID ID: 0000-0002-4838-2154

Статівка О.М., здобувач вищої освіти, ННВЦ НУЦЗУ, м. Харків, ORCID ID: 0000-0001-6731-4029

Lopatchenko I., PhD of Public Administration, National University of Civil Defence of Ukraine, Kharkiv

Stativka O.M., Student, National university of civil defence of Ukraine, Kharkiv

\title{
ПУБЛІЧНЕ УПРАВЛІННЯ ПРОЦЕСАМИ ФОРМУВАННЯ ГЕНДЕРНОЇ ПОЛІТИКИ В УКРАЇНІ
}

\section{PUBLIC GOVERNANCE OF GENDER POLICY FORMATION PROCESSES IN UKRAINE}

В роботі розкритоосновні напрями удосконалення механізмів публічного управління процесами формування тендерної політики в Украӥні. Основною складовою публічного управління прочесами формування тендерної політики в Украӥні є механізм правового забезпечення. Визначено, що тендерна політика в Украӥні має бути одним із пріоритетних напрямків діяльності держави. Було здійснено аналіз стану державного регулювання тендерної політики в Україні. Запропоновано шляхи удосконалення публічного управління у сфері формування тендерної політики в Україні.

Ключові слова: публічне управління, тендерна політика, тендерна рівність.

The main directions of improving the mechanisms of public administrationof gender policy formation processes in Ukrainehave been revealed. The main component of public administrationt of the development of gender policyis the mechanism of legal support. It is determined that gender policy should be one of the priority areas of the state. The analysis of the state of state regulation of gender policy has been carried out. Ways to improve public administrationin the field of gender policy formation in Ukrainehave been suggested.

Keywords: public administration, gender policy, gender equality.

Постановка проблеми. Процес соціально-економічної перебудови в Україні супроводжується посиленням диференціації суспільства. Одним з ії проявів є гендерна нерівність, що нині притаманна всім державам незалежно від політичного устрою та рівня соціально-економічного розвитку, і проявляється в нерівних можливостях жінок і чоловіків у сфері політики, освіти та зайнятості, доходу та власності.

Цілі Розвитку Тисячоліття, прийняті світовим співтовариством ще на початку XXI століття, проголошують забезпечення гендерної рівності одним із пріоритетів міжнародного розвитку та індикатором соціально-економічного ро16 
звитку країни. Специфіка гендерних проблем в Україні виявляється у тому, що в державі не простежується гендерних відмінностей в доступі до базової освіти, для жінок характерні високі, за міжнародними стандартами, рівні економічної активності та зайнятості. Проте, ці сприятливі потенційні можливості супроводжуються значними гендерними диспропорціями в політиці та сфері державного управління, в можливостях доступу до гідної праці та економічних ресурсів. Це зумовлює необхідність ґендерних досліджень, спрямованих на забезпечення загальнолюдської справедливості щодо рівних прав та можливостей особи, незалежно від статі, соціального розвитку суспільства та економічного зростання держави на основі ефективного використання людського потенціалу. Оскількижінки становлять більше половини населення України, перехід до демократичного суспільства і ринкової економіки потребує їх рівноправного представництва в житті країни.

Важливою причиною необхідності забезпечення рівних прав чоловіків і жінок $є$ розвиток публічно-суспільних відносин Будь-яка державна влада зобов'язана відповідати на запити населення і його суспільних груп. Населення не $\epsilon$ однорідним, воно поділяється відповідно до різних індикаторів: статі, віку, освіти, мови тощо. Державна політика, спрямована на переважне забезпечення інтересів однієї із суспільних груп, яка виокремлюється такими індикаторами, не може бути ефективною. В однаковій мірі це твердження стосується і гендерного аспекту.

Аналіз останніх досліджень і публікацій. У світовій практиці вже існує значна теоретична та методична база 3 цього питання. Основи гендерних досліджень сформовані зарубіжними науковцями Дж.Анкером, Т.Верленом, К.Делфі, М.Кіммелом, Дж.Скотт, Х.Хартман.

Серед вітчизняних авторів, які працюють над вивченням специфіки формування гендерної політики української держави, жіночим політичним лідерством, тендерними стереотипами та міфами масової свідомості, можна назвати Т.Мельник, Л. Кобилянську, К.Б.Левченко, Н. Грицяк О.Кулачек, С.Плотяна, М.Скорик, Л.Малес, В. Буроменського, С.Оксамитну, О.Суслову, Ю.Галустян, Е.Плісовську, Н.Римашевську та інших.

Метою статті $є$ розробка практичних рекомендацій щодо вдосконалення діяльності органів публічного управління у забезпеченні реалізації гендерної політики в Україні.

Виклад основного матеріалу дослідження. Характерною особливістю сьогодення є розгляд прав людини в контексті розвитку людини і суспільства. I хоча прогрес в галузі прав людини вважається одним з основних досягнень XX ст., основний принцип прав людини - гарантії свободи, добробуту та гідності для всіх людей - поки що не реалізований. Серед тих „свобод”, які входять в контекст принципу прав людини, свобода від дискримінації, в тому числі за ознакою статі, $є$ першою Держава, яка гарантує права людини і реально дбає про їх забезпечення, повинна визнати гендерний принцип складовою своєї державної політики. 
За декларативним визначенням людські права мають універсальний характер, який полягає в тому, що всі люди визнаються рівними, мають цінність як людська особистість та невід'ємні права. Але ця концепція універсальності прав не завжди визнавалась державами, особливо коли йдеться про права жінок, а точніше, про їх порушення.

Гендерні перетворення в Україні збіглися з загальними процесами реформування, перебудови, оновлення всієї системи ії політичного, економічного та соціального життя.Перехідне суспільство зумовлює й перехід жінки та чоловіка до нового стану і способу їх життєдіяльності як політичної. Перебування на межі якісно старого та нового соціального буття статей $є$ етапом звільнення від такого стану та відбувається через гендерну адаптацію, що означає еволюціонування (а не просте сприйняття) до нових гендерних форм буття, прийняття їх як належних (а не просто пристосування), засвоєння (а не звичайне наслідування) їх як власних, органічно значущих цінностей. Процес гендерної адаптації статей до нових соціально-політичних відносин тісно пов'язаний із соціальнополітичним оновленням суспільства загалом. Україна не може розвиватися відокремлено від світового розвитку і світової політичної й гендерної думки.

Національні особливості прояву та вираження відмінностей жіночих і чоловічих начал історично стримувалися або прискорювалися в розвитку залежно від того, які відносини влади, власності тощо панували в той чи інший період, які ідеологічні та політичні постулати проголошувалися, як розвивалися і вкорінювалися соціальні норми (зокрема право й мораль) та як змінювалося ставлення до особистості представників обох статей, а згодом і до людини якнайвищої соціальної цінності. Таке ставлення до людини як суб'єкта політики зумовлює потребу в політиці творення суспільства гендерної рівності.Просуваючись на шляху інтегрування в європейське співтовариство, Україна орієнтується на досягнуті там стандарти, в тому числі і в питаннях гендерної політики. Адже гендерна політика визначена у міжнародному і європейському праві як пріоритетний напрямок світового і національного розвитку. Україна підписала базові міжнародні документи з питань рівноправності і взяла на себе відповідні зобов'язання, які потрібно виконувати. Ці зобов'язання розглядаються в Україні не лише як частина міжнародних зобов'язань держави перед світовим співтовариством, але, в першу чергу, як обов'язок перед власними громадянами [3].

Особливістю формування державної гендерної політики в Україні є те, що вона будується на основі міжнародних нормативно-правових актів, ратифікованих Україною та регулюється національним законодавством щодо рівноправності між жінками і чоловіками [4].

До нормативно-правових актів наднаціонального рівня відносяться:

- Загальна декларація прав людини;

- Міжнародний пакт ООН про економічні, соціальні і культурні права;

- Міжнародний пакт ООН про громадянські та політичні права;

- Конвенція ООН про ліквідацію всіх форм дискримінації щодо жінок 
та факультативний протокол до неї;

- Декларація ООН про соціальний прогрес;

- Декларація та Платформа дій, прийняті на четвертій Всесвітній конференції зі становища жінок;

- Декларація глав держав і урядів, прийнята на Самміті Тисячоліття;

- Підсумковий документ Всесвітнього самміту 2005 року;

- Європейська конвенція про захист прав людини та основних свобод [3].

Крім того, цілями тисячоліття ООН (Ціль 6 - забезпечення гендерної рівності ) передбачено забезпечити гендерне співвідношення на рівні від 30 до $70 \%$ для будь-якої статі в представницьких органах влади та у вищих органах виконавчої влади, а також скорочення розриву у доходах жінок і чоловіків удвічі [7]. Положення цих та інших міжнародних документів вимагають відповідних змін до законодавства України. Серед інших такими міжнародними документами $є$ Угода про партнерство та співробітництво між Україною та і Європейським Союзом.Стратегія інтеграція України в Свропейський Союз, Програма інтеграції України до ЄС, Загальнодержавна програма адаптації законодавства України до законодавства Європейського Союзу, а також План дій Україна - СС [2].

3 прийняттям Основного Закону конституційно-правове регулювання рівних прав та можливостей жінок і чоловіків в Україні не тільки не завершилося, а навпаки, активізується й поглиблюється завдяки конкретизації відповідних конституційних норм у кодексах, законах, постановах, указах, розпорядженнях та інших правових актах національного рівня. Поступово, але наполегливо гендерні ідеї завойовували уми політиків і крок за кроком наша держава просувалась вперед у формуванні повноцінної гендерної політики [3].

Однак, незважаючи на вищезазначені кроки, в Україні спостерігаються прояви гендерної дискримінації як у відкритій, так і у прихованій формі. Розриви у реальному економічному і майновому становищі жінок і чоловіків, у політичному представництві та доступі до ресурсів і фінансів не можуть бути проігноровані при розробці державних стратегій, програм і проектів [3].

Серед найбільш гострих нерозв'язаних гендерних проблем -відсутність паритетного представництва жінок у прийнятті рішень на вищих представницьких та управлінських рівнях.

За співвідношенням загальної кількості чоловіків і жінок на державній службі - переважають жінки. Проте частка жінок традиційно знижується з підвищенням рівня службових посад. Статистика свідчить, що хоча серед загальної кількості державних службовців жінки складають 75\%, на посадах найвищої категорії жінок лише 7\%, а на посадах найнижчої категорії - 68\%. Серед керівників першої категорії посад жінок лише 14\%.

Низький відсоток представництва жінок в органах влади неминуче призвів до зниження їх впливу на прийняття найважливіших державних рішень. Тобто, становлячи 54 відсотка населення України, жінки можуть лише несуттє- 
во впливати на формування багатьох аспектів зовнішньої та внутрішньої політики. Для реалізації гендерної політики потрібен державний механізм. Цей процес відбувається складно, навіть болісно, але він прямує до формування того, що можна визначати як державну гендерну політику.

Державна гендерна політика- це діяльність (або бездіяльність у разі навмисного не провадження такої політики) державних інституцій, спрямована на здійснення (безпосередньо або опосередковано) на гарантування рівних прав, свобод і можливостей для жінок і чоловіків, утвердження гендерної демократії та формування гендерної культури в суспільстві. Оскільки реальне становище жінки суттєво відрізняється від становища чоловіка, то особливий наголос у структурі гендерних стратегій і їх реалізації ставиться завжди на політиці щодо поліпшення становища жінок. I це справедливо. Водночас така справедливість не унеможливлює, а, навпаки, передбачає в структурі гендерної політики наявність надзвичайно важливого іiі напряму - оновлення становища чоловіків стосовно формування гендерно якісніших, адекватних потребам сучасності світогляду, поведінки, громадських і державних форм діяльності, долання неадекватності сприйняття ними сучасних перетворень світового й національного рівнів, насамперед у сфері гендеру.

Отже, складниками державної гендерної політики є: політика щодо жінок, забезпечення їм рівного соціального статусу з чоловіками шляхом гарантування можливостей для їх рівноправного розвитку як соціальнодемографічної групи; політика щодо чоловіків, формування в них гендерної свідомості, культури гендерної поведінки, орієнтації на паритетність відносин 3 жінкою; державно-правове регулювання гендерних відносин; сприяння розвиткові гендерної демократії та гендерної культури в суспільстві [5].

Висновки. Таким чином, загальна концепція гендерної політики в Україні існує. Але вона містить переважно загальні напрями розвитку політики, рекомендації щодо поліпшення гендерної рівності, але основною проблемною ділянкою в гендерній державній політиці залишається вироблення національних механізмів дій. Тому актуальним питанням лишається спільна робота законодавців, науковців, громадських організацій щодо створення ефективної системи заходів впровадження задекларованих нормі пріоритетів у реальне суспільне життя.

Визнаючи, що українська спільнота знаходиться сьогодні фактично на початку шляху до суспільства рівної відповідальності за прийняття рішень серед жінок і чоловіків як громадян країни, як, зрештою, і на початку функціонування реального громадянського суспільства, аналітики все ж визнають, що Україна як держава сьогодні демонструє прагнення повністю відповідати принципам і засадам європейської демократії у плані формування державної гендерної політики. Враховуючи процесуальність суспільного поступу у напрямі утвердження певних цінностей, не можна не зазначити, що за роки української незалежності Україна як суспільна єдність і як держава пройшла значний відтинок шляху до становлення на їі теренах гендерно збалансованого суспільства. 20 
I хоча сьогодні говорити про паритетну демократію щодо української спільноти можна лише як про ідеал в контексті євро інтеграційного вибору країни, цей напрям євро інтеграційних зусиль України залишається одним із найпослідовніших і чітко сформованих як через систему вже існуючої законодавчої бази, так і на рівні міжнародних угод [7].

\section{Список використаних джерел:}

1. Агеєва В. Жіночий простір: Феміністичний дискурс: Монографія. Київ: Факт, 2016. 320 с.

2. Гендерна експертизаукраїнськогозаконодавства (концептуальні засади) / Відп. ред. Т. М. Мельник. Київ : Логос, 2001. 120 с.

3. Гендерна політика в системі публічного управління України / М. Канавецьта ін.; за заг. ред. К. Ващенка. Київ: Центр адаптації державної служби до стандартів Свропейського Союзу, 2018. 125 с.

4. Закон України «Про забезпеченнярівних прав та можливостейжінок i чоловіків» від 8 вересня 2005 року № 2866-IV. URL: https://zakon.rada.gov.ua/laws/show/2866-15(дата звернення: 15.03.2021).

5. Методичні рекомендації з проведення гендерно-правової експертизи актів законодавства та проектів нормативно-правових актів, затверджені наказом Міністерства юстиції України від 27 листопада 2018 року №3719/5.

6. Олійник А.С.Конституційне законодавство України: Гендерна експертиза. Київ: Логос, 2001. 77 с.

7. Постанова КабінетуМіністрівУкраїнивід 28 листопада 2018 року №997 «Питанняпроведення гендерно-правовоїекспертизи». URL: https://zakon.rada.gov.ua/laws/show/997-2018-п (дата звернення: 22.03.2021).

\section{References:}

1. Ageeva V. (2013). Zhinochyyprostir: Feministychnyydyskurs [Women's space: Feminist discourse]. Kyiv. Fact.

2. Gender examination of Ukrainian legislation (conceptual basis) (2001). T. M. Melnyk. Kyiv. Lohos.

3. Gender policy in the system of public administration of Ukraine (2018). Kyiv. Center for Adaptation of the Civil Service to the Standards of the European Union.

4. The Law of Ukraine «On ensuring equal rights and opportunities for women and men» of September 8, 2005 № 2866- IV: https://zakon.rada.gov.ua/laws/show/2866-15.

5. Methodical recommendations for conducting a gender legal examination of acts of legislation and draft legal acts,approved by the Order of the Ministry of Justice of Ukraine dated November 27, 2018, No. 3719/5.

6. Oliinyk A. S. (2001). KonstytutsiynezakonodavstvoUkrayiny: Gendernaekspertyza [Constitutional legislation of Ukraine. Gender expertise]. Kyiv. Lohos.

7. Resolution of the Cabinet of Ministers of Ukraine dated November 28, 2018 No. 997 Issues of gender legalexamination: https://zakon.rada.gov.ua/laws/show/997-2018-p. 